\title{
PNEUMOPERITONEUM DUE TO PERFORATED APPENDICITIS: A RARE ANATOMO-RADIOLOGIC CORRELATION
}

\section{Pneumoperitônio devido à apendicite perfurada: correlação anátomo-radiológica rara}

\author{
André Luiz Santos RODRIGUES, Marcelino Ferreira LOBATO, Augusto César SANTANA, \\ Lucas Crociati MEGUINS, Daniel Felgueiras ROLO
}

ABCDDV/613

\begin{abstract}
Rodrigues ALS, Lobato MF, Santana AC, Meguins LC, Rolo DF. Pneumoperitoneum due to perforated appendicitis: a rare anatomo-radiologic correlation. ABCD Arq Bras Cir Dig 2008;21(3):142-3

ABSTRACT - Background - Pneumoperitoneum is usually associated with a perforated peptic ulcer. However, perforated appendicits may be evolved on it. In the medical literature, the anatomo-radiologic correlation between them is an uncommon event. Case report - Man with 56-year-old look for assistance with diffuse abdominal pain and distension associated with fever, vomit and absence of flatus and evacuation for about 14 days. The chest radiography revealed a pneumoperitoneum. Diffuse peritonitis was found during the exploratory laparotomy. Appendectomy, peritoneal cavity cleaning and drainage with tubular drains were carried out. However, severe sepsis occurred and the patient died on the 16th post-operative day with multiple systemic organ failure. Conclusion - Although rare as pneumoperitoneum ethiology, acute appendicitis may be thought as it's cause. HEADINGS - Pneumoperitoneum. Appendicitis. Surgery. Radiology.
\end{abstract}

\section{INTRODUCTION}

Pneumoperitoneum is a very common radiologic sign in patients with perforated peptic ulcer ${ }^{1,4,5}$. Much less likely, other gastrointestinal diseases may present $t^{1,2,3,4,5}$. The anatomo-radiologic correlation between them is a rare clinical event and frequently may lead to a diagnostic misinterpretation.

\section{CASE REPORT}

A 56-year-old man, presented to medical assistance with abdominal pain and distension associated with fever, vomit, absence of flatus and evacuation for about 14 days. He also reported treatment with herbal teas in the beginning, but without any success. The physical examination revealed a painful facial expression, anemia and severe dehydration. The abdomen was distended, tympanic, and diffusely painful on palpation mainly on right iliac fossae with Joubert's and Blumberg's signs. Leukocytosis (13.410/ $\mathrm{mm}^{3}$ ), hypernatremia and hyperazotemia were present. Chest X-ray showed a pneumoperitoneum (Figure 1). The

From the Department of Surgery, Hospital de Pronto-Socorro Municipal "Dr. Humberto Maradei Pereira”, Belém, PA, Brazil.

Correspondence: André L S Rodrigues, e-mail: santosrodrigues@superig.com.br abdomen's radiography revealed a distension of the intestinal loop with hydroaereal signs and pneumoperitoneum. The patient went to surgerywith an exploratory laparotomy revealing diffuse peritonitis due to perforated appendicitis. Appendectomy, peritoneal cavity cleaning and drainage with tubular drains were carried out. After surgery, in intensive care unit, received Ertapenem $1 \mathrm{~g}$ daily but severe sepsis lead him to death on the $16^{\text {th }}$ post-operative day with multiple systemic failure.
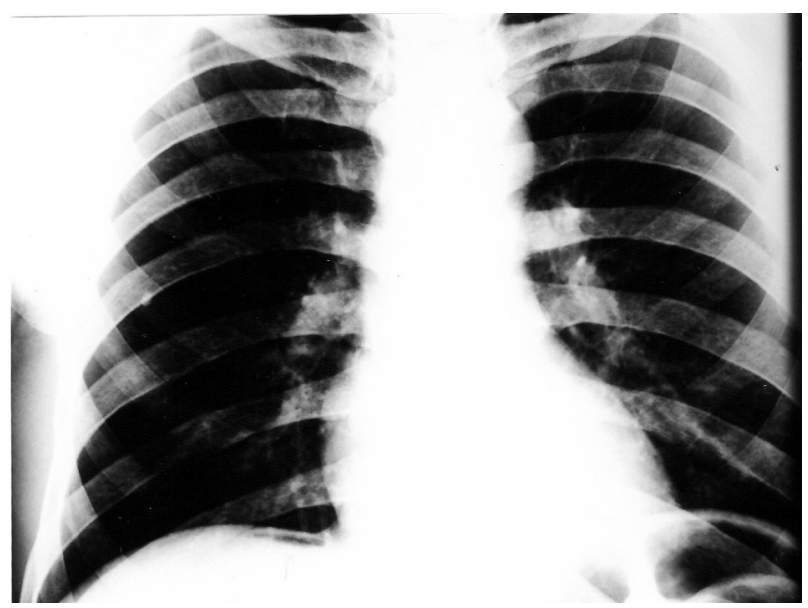

FIGURE 1 - Chest radiography revealing a pneumoperitoneum due to a perforated appendicitis 


\section{DISCUSSION}

Peritonitis caused by appendicitis is not usually related to pneumoperitoneum. It is a very rare situation reported on the medical literature with at most $7 \%$ estimated incidence ${ }^{2,4}$. Few authors published anatomo-radiologic correlation between perforated appendicitis and pneumoperitoneum, but it can be more common than usually related in literature due to the lack of X-ray evaluation in established acute appendicitis ${ }^{1,2}$.

Two theories may explain the pathophysiologic mechanism for this correlation: 1) intestinal gas escapes from the perforated appendix and, 2) the increase in the gas production by the peri-appendicular abscess' bacteria ${ }^{2,4}$. In the present case, the first theory is probably the most appropriate to explain.

Körner et al. ${ }^{3}$ reported that patients with perforated appendicitis have an increase in the duration of the clinical symptoms and signs than patients with non-perforated appendicitis. This observation had been observed in our case.

\section{CONCLUSION}

Although rare as pneumoperitoneum ethiology, acute appendicitis may be thought as it's cause.

Rodrigues ALS, Lobato MF, Santana AC, Meguins LC, Rolo DF. Pneumoperitônio devido à apendicite perfurada: correlação anátomo-radiológica rara. ABCD Arq Bras Cir Dig 2008;21(3):142-3

RESUMO - Introdução - Penumoperitôneo é usualmente associado à perfuração gástrica ou duodenal. Entretanto, apendicite perfurada pode também desenvolvê-lo. Na literatura, correlação clínica-radiológica é rara nesses eventos. Relato do caso - Homem com 56 anos foi atendido com dor abdominal difusa, distensão abdominal e febre, vômitos, parada de eliminação de gazes e fezes por 14 dias. Estudo radiológico de tórax mostrou pneumoperitôneo. No procedimento cirúrgico, peritonite difusa foi encontrada e apendicectomia com lavagem abdominal e drenagem foi efetuada. Entretanto, o paciente morreu por sepse generalizada e falência múltipla de órgãos e sistemas no 16o. dia do pós-operatório. Conclusão-Embora rara como causa de pneumoperiotôneo, a apendicite aguda deve ser pensada como sua possível causa.

DESCRITORES - Pneumoperitônio. Apendicite. Cirurgia. Radiologia.

\section{REFERÊNCIAS}

1. Cannova JV, Krummen DM, Nicholson OO. Pneumoperitoneum in association with perforated appendicitis. Am Surg. 1995 Apr;61(4):324-5.

2. Cizmeli MO, Demirag A, Durmus O, Ilgit E. Acute appendicitis associated with pneumoperitoneum. Br J Clin Pract. 1990 Dec;44(12):646-7.

3. Körner H, Söndenaa K, Söreide JA, Andersen E, Nysted A, Lende TH, Kjellevold KH. Incidence of acute nonperforated and perforated appendicitis: agespecific and sex-specific analysis. World J Surg. 1997 Mar-Apr;21(3):313-7.
4. Loizate Totorikagüena A, Lamíquiz Vallejo A, Ramos Prada J, Acha Arrizabalaga A. Pneumoperitoneum caused by perforated acute appendicitis Rev Esp Enferm Apar Dig. 1988 Nov;74(5):556-8.

5. Roh JJ, Thompson JS, Harned RK, Hodgson PE. Value of pneumoperitoneum in the diagnosis of visceral perforation. Am J Surg. 1983 Dec;146(6):830-3.

Fonte de financiamento: não há Conflito de interesse: não há Recebido para publicação: 31/11/2007 Aceito para publicação: 03/03/2008 